\title{
Application of Data Mining in Determining Social Assistance Recipients With C4.5 Algorithm in Maligas Mountain District
}

\author{
Rika Nur Adiha ${ }^{1}$, Sundari Retno Andani ${ }^{2}$, Widodo Saputra ${ }^{3}$ \\ ${ }^{1}$ STIKOM Tunas Bangsa Pematangsiantar, North Sumatra, Indonesia \\ ${ }^{2,3}$ AMIK Tunas Bangsa Pematangsiantar, North Sumatra, Indonesia
}

Article Info

Article history:

Received Sep 9, 2021

Revised Oct 20, 2021

Accepted Nov 02, 2021

\section{Keywords:}

Data Mining;

Classification;

C4.5 Algorithm;

Social Assistance.

\begin{abstract}
The Gunung Maligas District Office is a government agency tasked with running a government program, namely the Social Assistance Receipt program, to run the social assistance program, many residents complain that they do not receive assistance, while some residents who are considered capable actually get assistance, where each aid program is have different criteria in determining the recipient. Due to the large number of existing aid programs with different criteria in determining the acceptance of the aid program, of course, local government staff will have difficulty in conducting the selection process. So we need a system that is able to help local government staff to more easily determine the recipients of the social assistance. Based on the historical data of beneficiaries, recommendations for the classification of beneficiaries can be made that will assist government staff. Classification can be done using the $\mathrm{C}_{4} .5$ algorithm. In this study, it has parameters, namely, occupation, income, housing conditions and number of dependents. By applying the $\mathrm{C}_{4.5}$ data mining algorithm, it is hoped that it will make it easier and faster for government staff to determine the recipients of social assistance at the Gunung Maligas District Office.
\end{abstract}

This is an open access article under the CC BY-NC license.

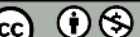

\section{Corresponding Author:}

Rika Nur Adiha,

STIKOM Tunas Bangsa Pematangsiantar,

Jl. Jend. Sudirman Block A No.1-3 Pematangsiantar, North Sumatera - Indonesia

Email: rikaadiha9@gmail.com

\section{INTRODUCTION}

The social welfare of the community is always faced with various kinds of problems. Social problems such as poverty that will have an impact on people's lives. To overcome this problem, the government provides assistance [1],[2]. Social assistance is assistance in the form of money or goods that are not continuous and selective which aims to improve people's welfare [3],[4],[5]. To overcome this problem, the Gunung Maligas District Office always routinely implements the government program regarding the provision of social assistance to underprivileged residents [6],[7]. The assistance program is one of the cash social assistance programs (BST), where each aid program has a 
procedure, the Gunung Maligas Sub-district Office has a procedure, namely by conducting a selection process for each citizen, each aid program has different criteria in determining the recipient. With so many existing aid programs with different criteria, of course, local government staff will find it difficult to carry out the selection process [8],[9]. Based on these problems, a method is needed to make it easier to determine beneficiaries so that the people who get assistance are recipients who really need or are right on target [10],[11].

One method that can be used in this research is the application of data mining algorithm $\mathrm{C}_{4.5}$ [12],[13]. In determining the classification of aid program recipients based on predetermined variables [14],[15]. By using the $\mathrm{C}_{4.5}$ algorithm, it is expected to produce a decision tree model that can predict families who are eligible to receive assistance programs and can assist local government staff in determining decision trees [16],[17]. Previous research by Hariati et all, on the application of the $\mathrm{C}_{4.5}$ Algorithm in determining the recipients of local government assistance programs in Kutai Kartanegara district obtained the results that the $\mathrm{C}_{4.5}$ algorithm can be applied to the application of determining the recipients of local government assistance programs by using a rule formed from the results. the highest accuracy on training data is $85 \%$ with a total of 105 data [18].

\section{RESEARCH METHOD}

The following will explain how to describe the scientific way to solve research problems. The method used in this study is the $\mathrm{C}_{4} .5$ Algorithm. The results of this study were carried out to produce a decision rule tree model for recipients of social assistance programs in accordance with the requirements. The research design carried out for determining the recipients of social assistance using the $\mathrm{C}_{4.5} \mathrm{algorithm}$ begins by analyzing problems related to recipients of social assistance and determining the variables used. Furthermore, studying literature is based on references made to obtain information in research. Collecting data using a questionnaire by distributing it to people who receive social assistance, then Analysis is a process carried out for determining social assistance recipients by using the variables used in the study. Implementation using the Rapidminer version 5.3 application as a tool and the results are the results obtained from this research. It will be used as new knowledge in determining social assistance recipients. The data collection carried out in this study uses library research by utilizing libraries and journals as references used in research and field research, research is carried out directly in the field using questionnaires, literature studies, interviews and observations.

Work Activity Diagram The research carried out is described in the activity diagram in Figure 1 below: 


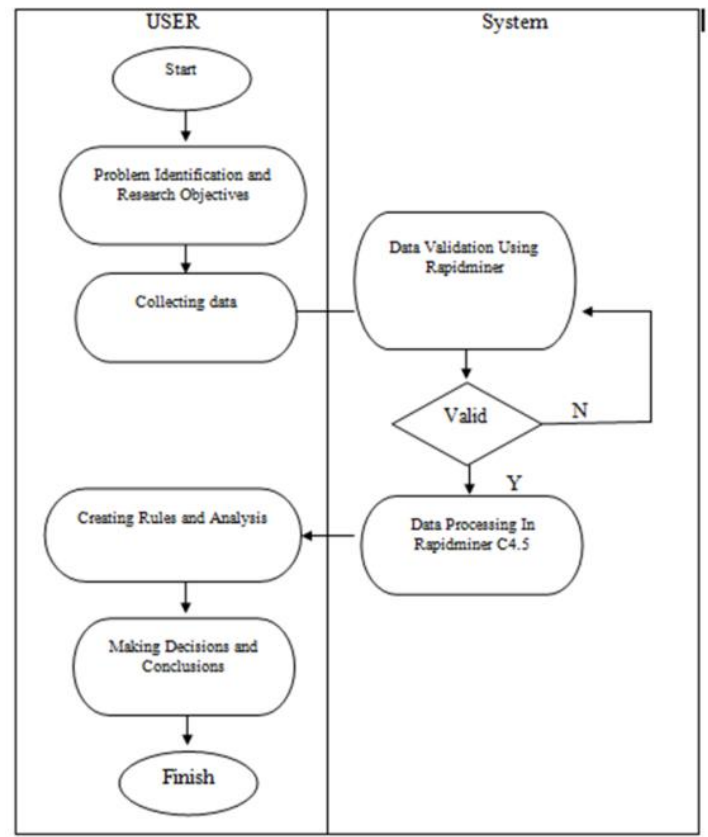

Figure 1. Research Activity Diagram

Figure 1 describes the author or user in identifying the problem and the purpose of the research carried out, collecting data in the form of a questionnaire given, on the Rapidminer application.

\section{RESULTS AND DISCUSSION}

In this study, the authors obtained data from the questionnaire results from the Gunung Maligas sub-district office with a total of 50 data. To make it as a root, it was based on the highest gain value of the existing attributes. To calculate the gain, use a formula like the following [19],[20],[21] :

$\operatorname{Gain}(S, A)=\operatorname{Entropy}(S)-\sum_{i=1}^{n} \frac{|S i|}{|S|} * \operatorname{Entropy}(S i)$

Information:

A $=$ Attribute

$\mathrm{S} \quad=$ Set of cases

S1 $\quad=$ Number of samples

Before getting the gain value, the entropy value is sought first. To find the entropy value, use the following formula [22],[23],[24]:

$E(s)=\sum_{i=1}^{n}-p i * \log _{2}(P i)$

Information:

$\mathrm{S} \quad=$ Set of cases

S1 $\quad=$ Number of samples

$\mathrm{Pi} \quad=$ Proportion

Data Processing Using $\mathrm{C}_{4} .5$. Algorithm, The following are the steps of data processing with the $\mathrm{C}_{4} .5$ Algorithm in order to obtain a model of decision tree rules for social assistance recipients in accordance with the data obtained from the questionnaire. For the calculation of the $\mathrm{C}_{4.5}$ algorithm, it can be described as follows [25]: 
Step 1: Counting the number of cases, the number of cases for a feasible decision, and the number of cases for an invalid decision. Calculating the total Entropy:

Entropy $[$ Total $]=-\left(\frac{19}{50}\right) \times \log 2\left(\frac{19}{50}\right)-\left(\frac{31}{50}\right) \times \log 2\left(\frac{31}{50}\right)=0,958042$

Step 2: Then, calculate the entropy and gain for each data attribute. The following is the calculation of the Entropy and Gain values. Calculating Entropy and Job Gain:

$\begin{array}{ll}\text { Entropy [Work-Labor] } & =-\left(\frac{0}{21}\right) \times \log 2\left(\frac{0}{21}\right)-\left(\frac{21}{21}\right) \times \log 2\left(\frac{21}{21}\right)=0 \\ \text { Entropy [Job-PNS] } & =-\left(\frac{7}{7}\right) \times \log 2\left(\frac{7}{7}\right)-\left(\frac{0}{7}\right) \times \log 2\left(\frac{0}{7}\right)=0\end{array}$

Entropy [Job-Entrepreneur] $=-\left(\frac{5}{12}\right) x \log 2\left(\frac{5}{12}\right)-\left(\frac{7}{12}\right) x \log 2\left(\frac{7}{12}\right)=0,979869$

Entropy [Private-Employee Job] $=-\left(\frac{7}{10}\right) x \log 2\left(\frac{7}{10}\right)-\left(\frac{3}{10}\right) x \log 2\left(\frac{3}{10}\right)=0,881291$

Gain [Total, Employment] $=0,958042-\left(\left(\frac{21}{50}\right) x 0+\left(\frac{7}{50}\right) x 0+\left(\frac{12}{50}\right) x 0,979869+\left(\frac{10}{50}\right) x 0,881291=\right.$ $0,546615)$

Calculating Entropy and Gain Reliability:

Entropy [Excellent-Earning] $=-\left(\frac{3}{3}\right) x \log 2\left(\frac{3}{3}\right)-\left(\frac{0}{3}\right) x \log 2\left(\frac{0}{3}\right)=0$

Entropy [Good-Income] $=-\left(\frac{4}{4}\right) x \log 2\left(\frac{4}{4}\right)-\left(\frac{0}{4}\right) x \log 2\left(\frac{0}{4}\right)=0$

Entropy [Income-Sufficient] $=-\left(\frac{11}{15}\right) x \log 2\left(\frac{11}{15}\right)-\left(\frac{4}{15}\right) x \log 2\left(\frac{4}{15}\right)=0,836641$

Entropy [Income-Low] $=-\left(\frac{0}{0}\right) x \log 2\left(\frac{0}{0}\right)-\left(\frac{19}{19}\right) x \log 2\left(\frac{19}{19}\right)=0$

Entropy [Income-Very Less] $=-\left(\frac{0}{0}\right) x \log 2\left(\frac{0}{0}\right)-\left(\frac{9}{9}\right) x \log 2\left(\frac{9}{9}\right)=0$

Gain [Total, Earnings] $=0,958042-\left(\left(\frac{3}{50}\right) x 0+\left(\frac{4}{50}\right) x 0+\left(\frac{15}{50}\right) x 0,836641+\left(\frac{19}{50}\right) x 0+\left(\frac{9}{50}\right)=0,707050\right)$

Then do the same calculation for the next variable. After that, the gain is calculated for each attribute. The calculation results are shown in table 1 below.

Table 1. Calculation Results of Node 1

\begin{tabular}{|c|c|c|c|c|c|c|}
\hline \multicolumn{2}{|r|}{ Node 1} & Amount & Worthy & Not Worthy & Entrophy & Gain \\
\hline \multirow{6}{*}{ Work } & Total & 50 & 31 & 19 & 0,958042 & \\
\hline & & & & & & 0,546615 \\
\hline & Laborer & 21 & 21 & o & 0,000000 & \\
\hline & PNS & 7 & o & 7 & 0,000000 & \\
\hline & Entrepreneur & 12 & 7 & 5 & 0,979869 & \\
\hline & Private employees & 10 & 3 & 7 & 0,881291 & \\
\hline \multirow[t]{6}{*}{ Income } & & & & & & 0,707050 \\
\hline & Very good & 3 & o & 3 & 0,000000 & \\
\hline & Good & 4 & o & 4 & o,oooooo & \\
\hline & Enough & 15 & 4 & 11 & 0,836641 & \\
\hline & Not enough & 19 & 19 & o & 0,000000 & \\
\hline & Very less & 9 & 9 & o & o,oooooo & \\
\hline \multirow[t]{4}{*}{$\begin{array}{c}\text { Dependent } \\
\text { Amount }\end{array}$} & & & & & & 0,13209 \\
\hline & A huge amount & 3 & 2 & 1 & 0,000000 & \\
\hline & Lots & 37 & 26 & 11 & 0,877962 & \\
\hline & A little & 10 & 3 & 7 & 0,881291 & \\
\hline
\end{tabular}




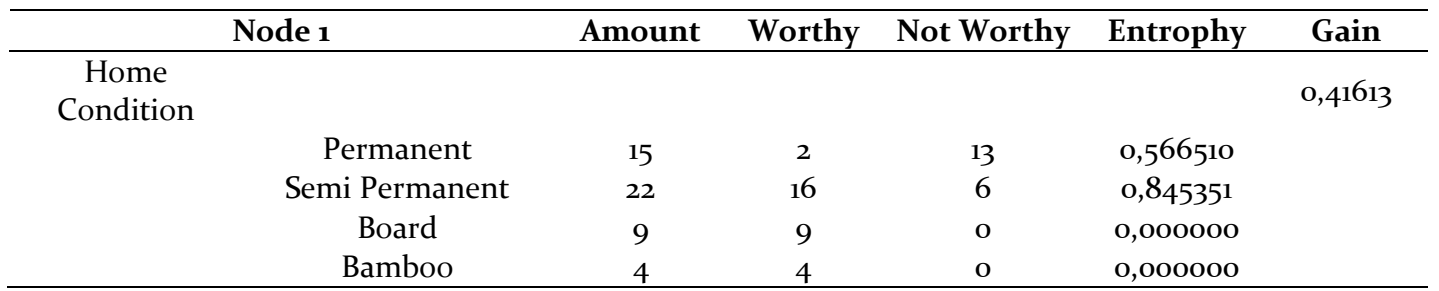

From the results of the calculations in table 4.1, the highest value obtained is the Income attribute with a Gain value of 0.707050 . So what is used as the root node is the Income attribute, which consists of five sub-attributes, namely Very good, Good, Enough, Not enough, and Very less. The decision tree obtained based on Node 1 calculations is as follows:

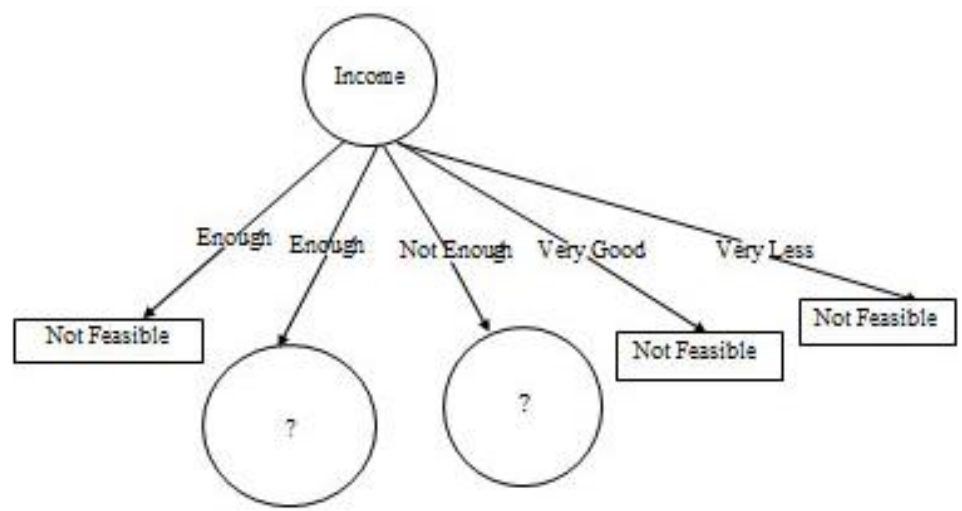

Figure 1. Decision Tree 1

From figure 1. from the calculation of Node 1, the Income attribute is used as the root node. As for the Enough and Not enough attribute classes based on the respective Entropy values, the results between the Worthy or Not Worthy decisions have not been obtained, so further calculations need to be carried out. The following is the result of the calculation of the Income = Enough attribute which can be seen in Table 2 .

Tabel 1. Node Calculation Results 1.1

\begin{tabular}{|c|c|c|c|c|c|c|}
\hline \multicolumn{2}{|c|}{ Node 1.1} & Amount & Worthy & Not Worthy & Entrophy & Gain \\
\hline \multicolumn{2}{|c|}{ Income $=$ Enough } & 15 & 4 & 11 & 0,836641 & \\
\hline \multirow[t]{5}{*}{ Work } & & & & & & 0,241995 \\
\hline & Laborer & o & o & o & o & \\
\hline & PNS & o & o & o & o & \\
\hline & Entrepreneur & 6 & o & 6 & o,oooooo & \\
\hline & Private employees & 9 & 4 & 5 & 0,991076 & \\
\hline \multicolumn{7}{|l|}{ Dependent } \\
\hline \multirow[t]{4}{*}{ Amount } & & & & & & 0,327609 \\
\hline & A huge amount & 1 & 1 & o & o,oooooo & \\
\hline & Lots & 8 & 3 & 5 & 0,954434 & \\
\hline & A little & 6 & o & 6 & 0,000000 & \\
\hline \multicolumn{7}{|l|}{ Home } \\
\hline & Permanent & 7 & o & 7 & 0,000000 & \\
\hline & Semi Permanent & 8 & 4 & 4 & 1,000000 & \\
\hline & Board & o & o & o & o,oooooo & \\
\hline & Bamboo & o & o & o & 0,000000 & \\
\hline
\end{tabular}


From Table 2. the calculation results that become branch nodes of Income-Enough are Dependent Amount with the highest Gain value of 0.327609 . The attribute class values A huge amount, and A little, are zero, so no calculation is necessary. The value of the Enough attribute class has classified one decision. The decision tree obtained based on the calculation of Node 1.1 is as follows:

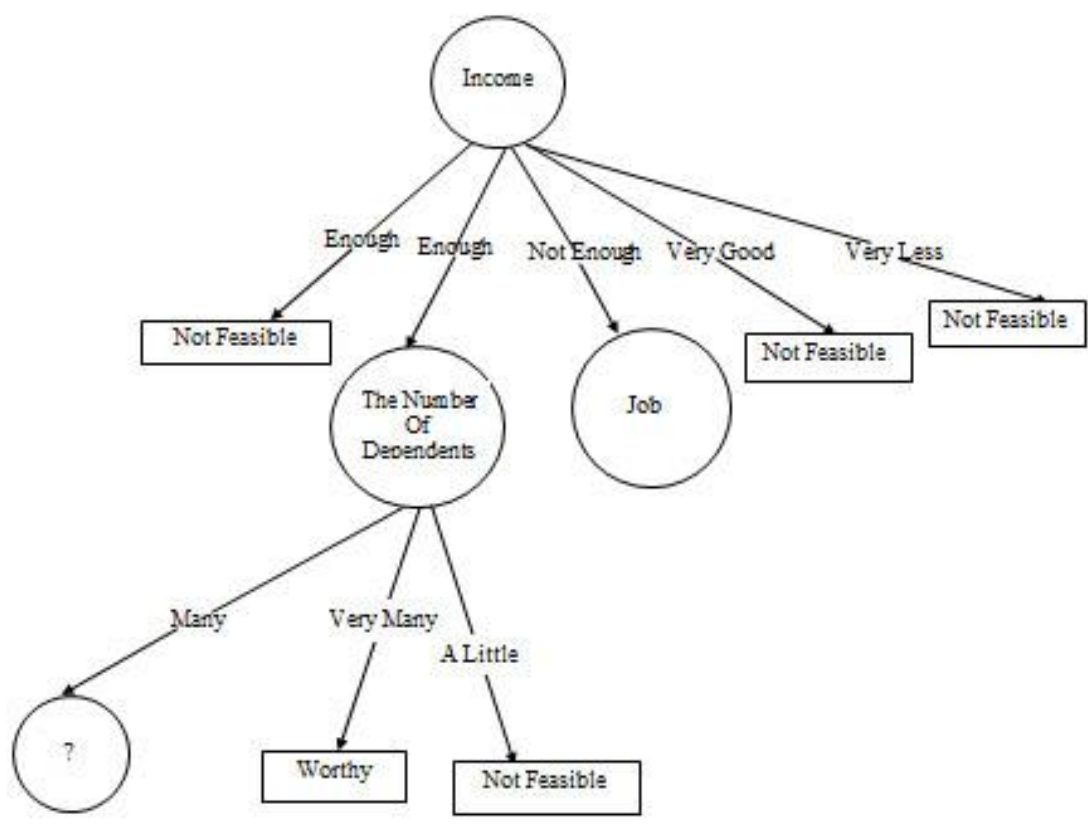

Figure 2. Decision Tree 2

In finding the results of the next calculation on the Income-Enough root node and the Dependent Amount-Lots branch node, it can be shown in the following table 3 .

Table 3. Node Calculation Results

\begin{tabular}{|c|c|c|c|c|c|}
\hline Node 1.2 & Amount & Satisfied & Not Satisfied & Entrophy & Gain \\
\hline $\begin{array}{c}\text { Income }=\text { Enough \& Dependent } \\
\text { Amount }=\text { Lots }\end{array}$ & 8 & 3 & 5 & 0,954434 & 0,548795 \\
\hline \multicolumn{6}{|l|}{ Work } \\
\hline Laborer & o & o & o & 0,000000 & \\
\hline PNS & o & o & o & 0,000000 & \\
\hline Entrepreneur & 4 & 1 & 3 & 0,811278 & \\
\hline Private employees & 4 & 2 & 2 & 1,000000 & \\
\hline \multirow{2}{*}{$\begin{array}{l}\text { Home } \\
\text { Condition }\end{array}$} & & & & & \\
\hline & & & & & o,048795 \\
\hline Permanent & 4 & 1 & 3 & 0,811278 & \\
\hline Semi Permanent & 4 & 2 & 2 & 1,000000 & \\
\hline Board & o & o & o & 0,000000 & \\
\hline Bamboo & $\mathrm{o}$ & o & o & o,o0oooo & \\
\hline
\end{tabular}


From the calculation results in table 3, the attributes that become branch nodes of Income - Enough and Dependent Amount - Lots are Work.. Where the attributes of Work consist of Laborers, PNS, Private employees, and Entrepreneurs. Where Laborer has obtained a decision, civil servants have obtained a decision. As for the sub-attributes Private employees and Entrepreneurs have not received a decision, it will be recalculated. Then the decision tree can be described from the table above as follows:

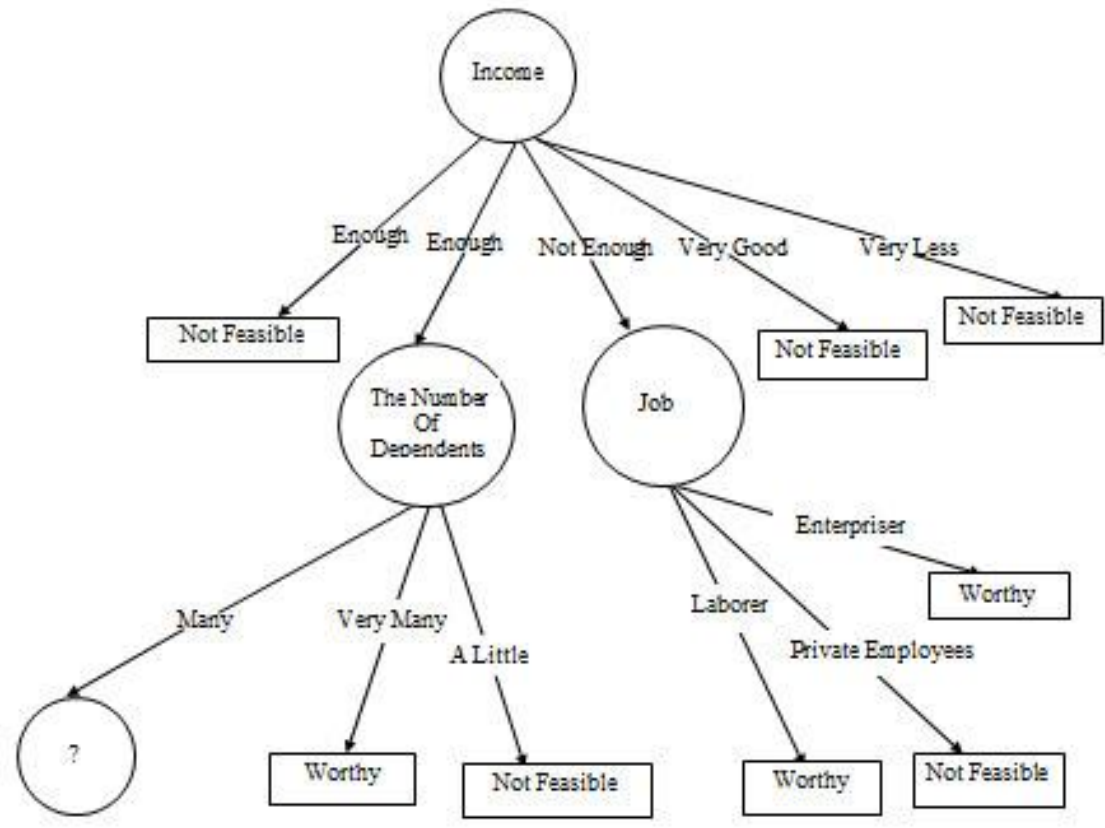

Figure 3. Decision Tree 3

Next, perform calculations on the branch nodes of the Income - Enough, Dependent Amount-Lots, Work-Private employees and Entrepreneur attributes as shown in table 4.

Table 4. Node Calculation Results 1.1.1

\begin{tabular}{|c|c|c|c|c|c|}
\hline Node 1.1.1 & Amount & Satisfied & $\begin{array}{c}\text { Not } \\
\text { Satisfied }\end{array}$ & Entrophy & Gain \\
\hline $\begin{array}{c}\text { Income }=\text { Enough \& Dependent Amount } \\
=\text { Lots \& Work = Private employees \& } \\
\text { Entrepreneur }\end{array}$ & 4 & 2 & 2 & 1,000000 & 0,000000 \\
\hline \multicolumn{6}{|l|}{ Home Condition } \\
\hline Permanent & 2 & 1 & 1 & 1,000000 & \\
\hline Semi Permanent & 2 & 1 & 1 & 1,000000 & \\
\hline Board & o & o & o & 0,000000 & \\
\hline Bamboo & o & o & o & o,oooooo & \\
\hline
\end{tabular}

From the calculation results in table 4, the attributes that become branch nodes of Income - Enough and Dependent Amount - Lots are Work. Where the attributes of Work consist of Laborers, PNS, Private employees, and Entrepreneurs. Where Laborer has obtained a decision, civil servants have obtained a decision. As for the sub-attributes Private employees and Entrepreneurs have not received a decision, it will be recalculated. Then the decision tree can be described from the table above as follows: 


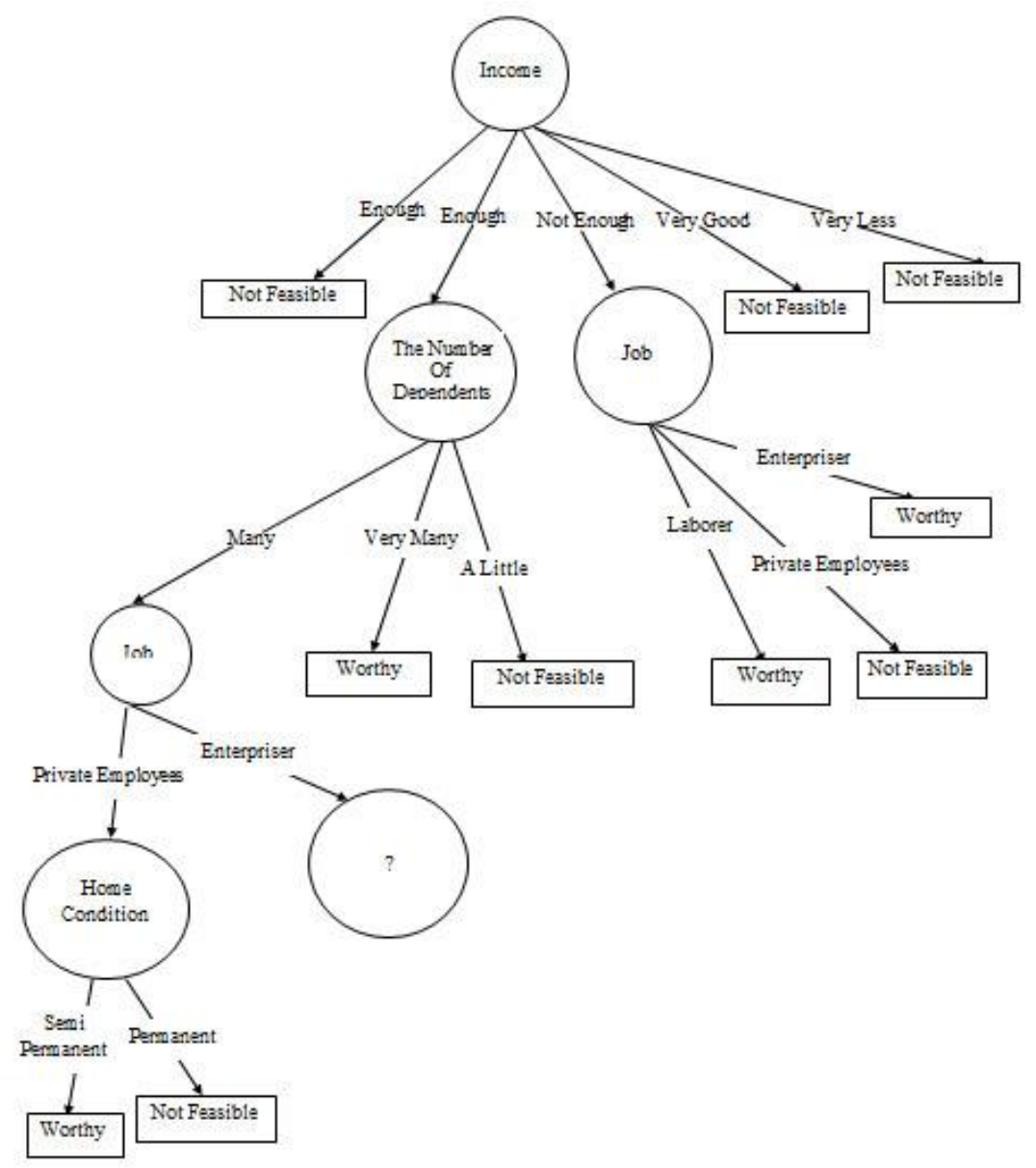

Figure 4. Decision Tree 4

Next, perform calculations on the branch nodes of the Income - Enough, Dependent Amount - Lots, Work - Private employees and Entrepreneur attributes as shown in table 5.

Table 5. Node Calculation Results 1.1.2

\begin{tabular}{|c|c|c|c|c|c|}
\hline Node 1.1.2 & Amount & Satisfied & $\begin{array}{c}\text { Not } \\
\text { Satisfied }\end{array}$ & Entrophy & Gain \\
\hline $\begin{array}{c}\text { Income }=\text { Enough \& Dependent } \\
\text { Amount }=\text { Lots \& Work = Private } \\
\text { employees \& Entrepreneur }\end{array}$ & 4 & 1 & 3 & 0,811278 & o,oooooo \\
\hline \multicolumn{6}{|l|}{ Home Condition } \\
\hline $\begin{array}{c}\text { Permanent } \\
\text { Semi }\end{array}$ & 4 & 1 & 3 & 0,811278 & \\
\hline Permanent & o & o & o & o,oooooo & \\
\hline Board & o & o & o & 0,000000 & \\
\hline Bamboo & o & o & o & 0,000000 & \\
\hline
\end{tabular}

From the above calculation results in table 5. The attributes that become branch nodes of Income Enough, Dependent Amount - Lots, Work-Private employees and Entrepreneurs, are Home Condition - Permanent, and Semi Permanent. Attributes from Home Condition - Permanent, Semi 
Permanent, Board, and Bamboo. Where Semi Permanent, Board, Bamboo already have a decision. Meanwhile, the Permanent sub attribute has not yet received a decision, so it will be recalculated. Then the decision tree can be described from the table above as follows:

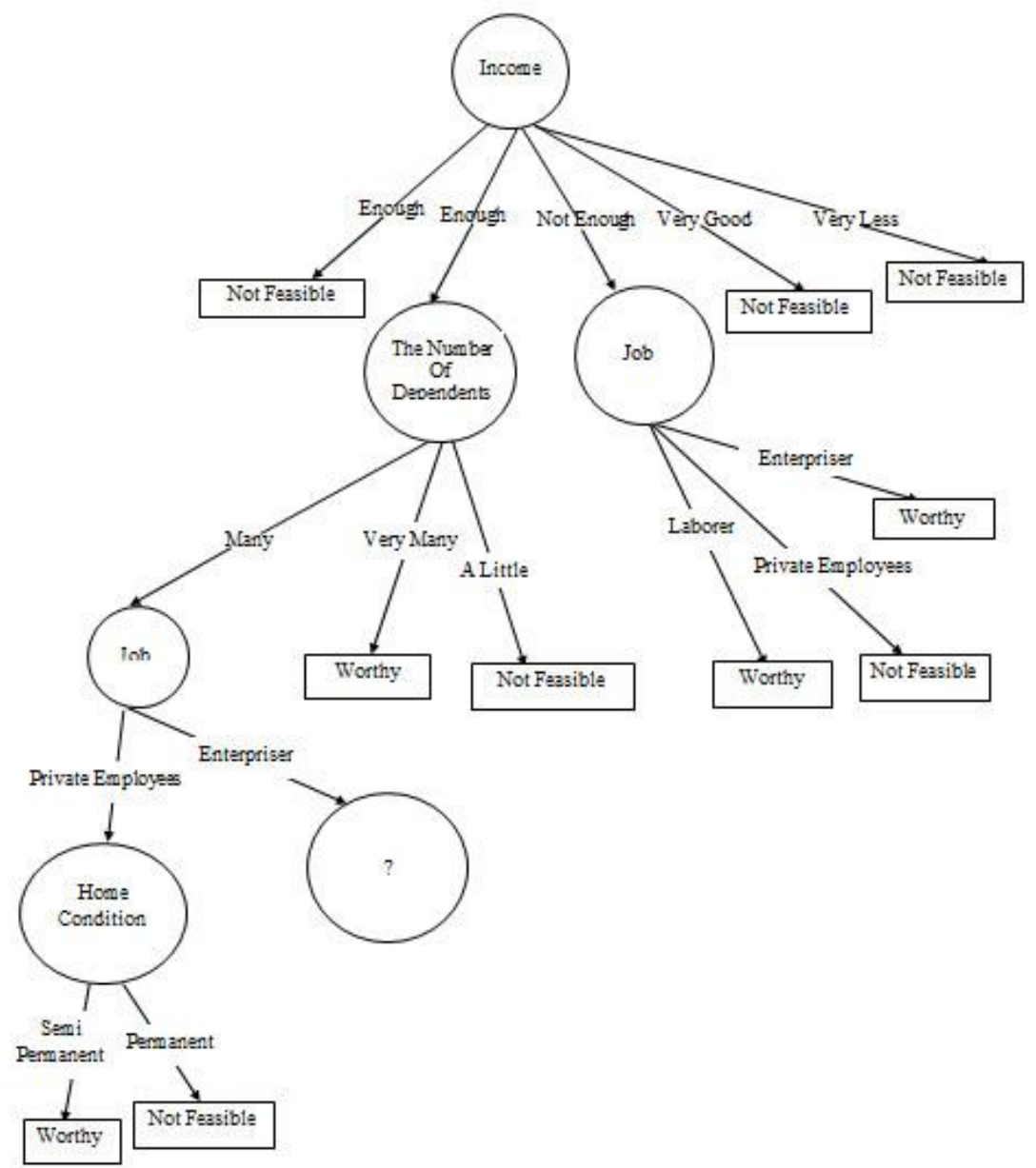

Figure 5. Decision Tree 5

Next, perform calculations on the branch nodes of the Income - Enough, Dependent Amount - Lots, Work - Private employees and Entrepreneur, Home Condition - Permanent attributes as shown in table 6 .

Table 6. Node Calculation 1.1.3

\begin{tabular}{|c|c|c|c|c|c|}
\hline Node 1.1.2 & Amount & Satisfied & $\begin{array}{c}\text { Not } \\
\text { Satisfied }\end{array}$ & Entrophy & Gain \\
\hline $\begin{array}{c}\text { Income }=\text { Enough \& Dependent } \\
\text { Amount }=\text { Lots \& Work = Private } \\
\text { employees \& Entrepreneur }\end{array}$ & 4 & 1 & 3 & 0,811278 & 0,000000 \\
\hline \multicolumn{6}{|l|}{ Home Condition } \\
\hline Permanent & 4 & 1 & 3 & 0,811278 & \\
\hline Semi Permanent & o & o & o & o,oooooo & \\
\hline Board & o & o & o & o,oooooo & \\
\hline Bamboo & o & o & o & 0,000000 & \\
\hline
\end{tabular}


From the above calculation results in table 6, the attributes that become branch nodes of IncomeEnough, Dependent Amount-Lots, Work-Private employees and Entrepreneurs, are Home Condition-Permanent, and Semi Permanent. Attributes of Home Condition-Permanent, Semi Permanent, Board, and Bamboo. Where the sub attributes Permanent, Semi Permanent, Board, Bamboo already have a decision so the calculation is complete. Then the decision tree can be described from the table above as follows:

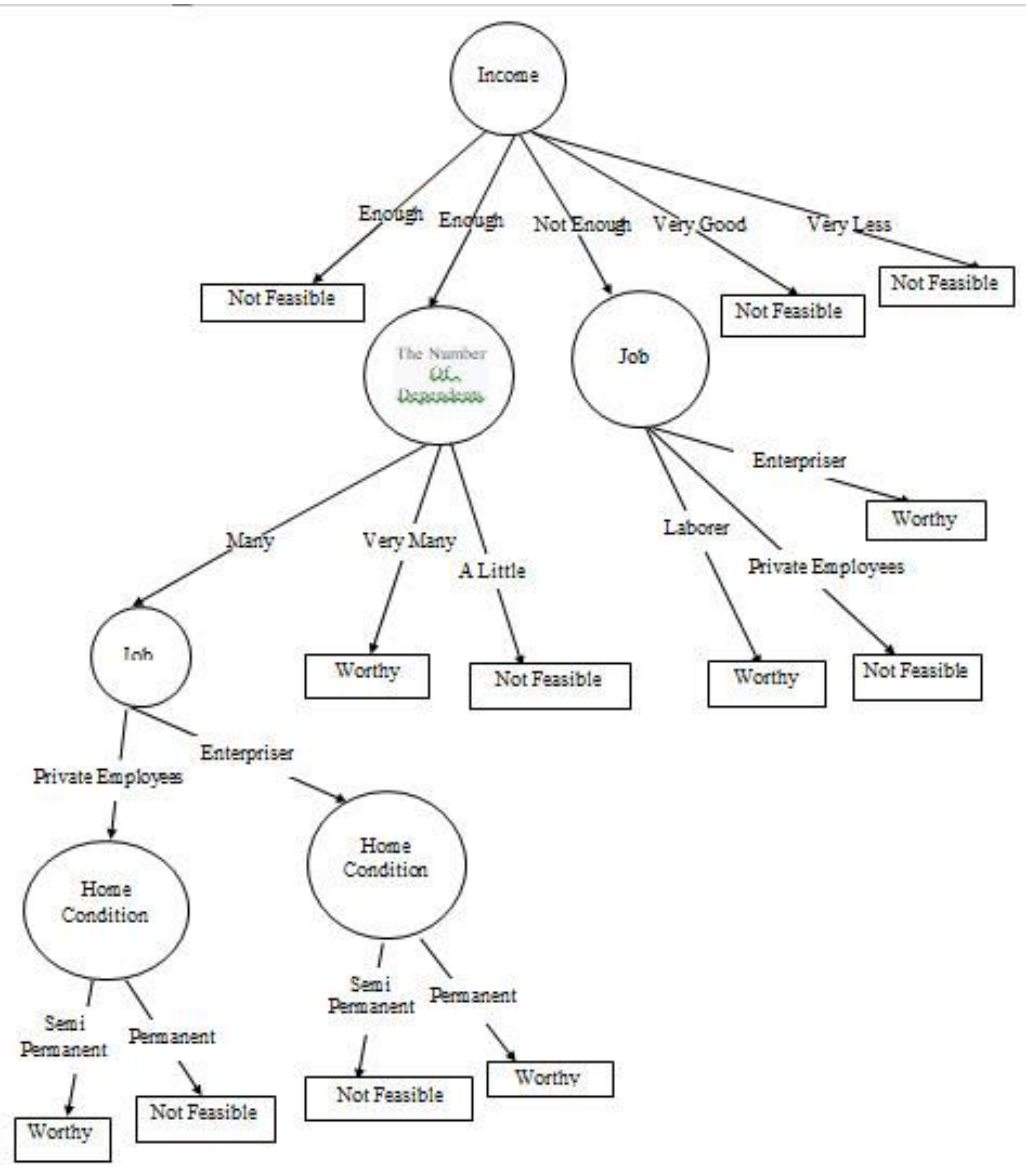

Figure 6. Decision Tree 6

In the calculation above, there are 12 rules that can be used as a reference in determining the main factors that influence the recipients of Social Assistance.

\section{CONCLUSION}

From the results of the research conducted, the conclusions that can be drawn based on the discussion of Social Assistance Recipients Using the $\mathrm{C}_{4.5}$ Algorithm are that the attribute that has the highest influence in determining the recipients of Social Assistance is Income. This is indicated by the Income attribute which occupies the root node in the decision tree diagram, and the Work attribute as the second factor in determining Social Assistance Recipients. It can be seen in the decision tree diagram that the Work attribute is located in a branch node under Income and based on the implementation of the test results with RapidMiner, a decision tree model is obtained that displays the rules that can be used for Social Assistance Recipients.

\section{REFERENCES}


[1] H. Y. Dama et al., "PENGARUH PRODUK DOMESTIK REGIONAL BRUTO ( PDRB ) TERHADAP TINGKAT KEMISKINAN DI KOTA MANADO,” vol. 16, no. 03, pp. 549-561, 2016.

[2] P. Febrianti et al., "TERHADAP ANAK TERLANTAR DI PANTI SOSIAL ASUHAN ANAK ( PSAA ) PUTRA UTAMA o3 TEBET," 2014.

[3] M. Luthfi, "Efektifitas Bantuan Sosial Program Keluarga Harapan Dalam Meningkatkan Kesejahteraan Keluarga," J. Comm-Edu, vol. 2, no. 1, pp. 81-89, 2019.

[4] K. Pintar, “'Virus Corona Jadi Pandemi Global ', Kelas Pintar, 1 April 2020,” vol. 2019, no. April, 2020.

[5] D. I. Manggarai, "BANTUAN SOSIAL DAN PENDIDIKAN KESEHATAN BAGI MASYARAKAT PESISIR YANG TERDAMPAK SOSIAL-EKONOMI SELAMA PATOGENESIS COVID-19 Pendahuluan,” vol. 16, no. 1, pp. 12-26, 2020.

[6] O. Nurdiawan, "Seleksi Penerima Bantuan Sosial Berdasarkan Sistem Pendukung Keputusan Dalam Upaya Mengurangi Siswa Rawan Putus Sekolah,” vol. XIII, pp. 32-40, 2018.

[7] J. P. Gultom and A. Rikki, "Implementasi Data Mining menggunakan Algoritma C-45 pada Data Masyarakat Kecamatan Garoga untuk Menentukan Pola Penerima Beras Raskin,” Kumpul. Artik. Karya Ilm. Fak. Ilmu Komput., vol. o2, no. o1, pp. 11-19, 2020.

[8] M. M. M. @EO $\Delta \Omega$ POY, G. B. Paz, and A. A. B. Ruíz, "EFEKTIVITAS PROGRAM PEMERINTAH DAERAH TENTANG PEMBERIAN BEASISWA UNTUK MAHASISWA BERPRESTASI DAN NOT ENOUGH MAMPU DALAM KEBIJAKAN NOMOR 18 TAHUN 2017 DI KABUPATEN LUWU TIMUR i SKRIPSI," vol. 3, no. 2017, pp. 54-67, 2020, [Online]. Available: http://repositorio.unan.edu.ni/2986/1/5624.pdf.

[9] F. Harahap, "Penerapan data Mining dalam Pemilihan Mobil menggunakan Algoritma C4.5," Ijccs, no. x, $\begin{array}{llll}\text { pp. } & \text { 201-20, } & \text { [Online]. Available: https://voi.stmik- }\end{array}$ tasikmalaya.ac.id/index.php/voi/article/viewFile/99/42.

[10] A. S. Febri Wulandari, "Sistem Pengklasifikasian Pemilihan Penerima Beras Miskin (Raskin) Menggunakan Metode Naïve Bayes Classifier (Nbc)," Progr. Stud. Tek. Inform. Fak. Teknol. Inf. Elektro, 2019.

[11] M. Jannah, K. O. Putra, and L. Tambunan, "Penerapan Metode Analytic Network Process ( ANP ) Dalam Menentukan Penerima Bantuan Langsung Tunai (BLT ),” SATIN - Sains dan Teknol. Inf., vol. o7, no. o1, pp. 81-90, 2021, doi: 10.33372/stn.v7i1.708.

[12] S. Adi, "Implementasi Algoritma Naive Bayes Classifier Untuk Klasifikasi Penerima Beasiswa PPA Di Universitas Amikom Yogyakarta,” J. Mantik Penusa, vol. 22, no. 1, pp. 11-16, 2018, [Online]. Available: http://e-jurnal.pelitanusantara.ac.id/index.php/mantik/article/view/342.

[13] B. Sugara, D. Widyatmoko, B. S. Prakoso, and D. M. Saputro, "Penerapan Algoritma C4.5 untuk Deteksi Dini Autisme Pada Anak," Semin. Nas. Teknol. Inf. dan Komun., vol. 2018, no. Sentika, pp. 87-96, 2018.

[14] A. A. Rahman and Y. I. Kurniawan, "Aplikasi Klasifikasi Penerima Kartu Indonesia Sehat Menggunakan," Progr. Stud. Inform. Univ. Muhammadiyah Surakarta, 2016.

[15] Q. Iman and A. Wahyu, "Klasifikasi Rumah Tangga Penerima Beras Miskin ( Raskin )/ Beras Sejahtera ( Rastra ) di Provinsi Jawa Barat Tahun 2017 dengan Metode Random Forest dan Support Vector Machine Classification of Poor Rice ( Raskin )/ Prosperous Rice ( Rastra ) Recipient Hou,” vol. o9, no. 2, pp. 178184, 2021, doi: 10.26418/justin.v9i2.44137.

[16] P. Pascasarjana, "Program pascasarjana," p. 2012, 2012.

[17] T. Kenikan, K. Di, S. D. N. Citamiang, and K. Sukabumi, "Penerapan algoritma c.45 untuk klasifikasi tingkat kenikan kelas di sdn citamiang 2 kota sukabumi," 2020.

[18] M. Wati, B. Cahyono, U. Mulawarman, D. Mining, and B. K. Kartanegara, "Penerapan Algoritma C4 · 5 pada Penentuan Penerima Program Bantuan Pemerintah Daerah di Kabupaten Kutai Kartanegara,” vol. 2, no. 2, pp. 106-114, 2018.

[19] H. S. T. 3 Eka Satria Pribadi 1, Poningsih 2, "Analisa Tingkat KeSatisfiedan Masyarakat Terhadap Pelayanan Pengadilan Agama Pematangsiantar Menggunakan Algoritma,” vol. 2, no. 1, pp. 33-40, 2020.

[20] T. Permana, A. M. Siregar, A. F. N. Masruriyah, and A. R. Juwita, "Perbandingan Hasil Prediksi Kredit Macet Pada Koperasi," Conf. Innov. Appl. Sci. Technol., vol. 3, no. 1, pp. 737-746, 2020, [Online].Available:http://publishing-widyagama.ac.id/ejournalv2/index.php/ciastech/article/view/1970.

[21] F. F. Harryanto, S. Hansun, U. M. Nusantara, G. Serpong, and C. Pegawai, "Penerapan Algoritma C4 5 untuk Memprediksi Penerimaan Calon Pegawai Baru di PT WISE,” vol. 3, no. 2, pp. 95-103, 2017.

[22] D. H. Kamagi and S. Hansun, "Implementasi Data Mining dengan Algoritma C4 . 5 untuk Memprediksi Tingkat Kelulusan Mahasiswa,” vol. VI, no. 1, pp. 15-20, 2014.

[23] S. Takalapeta, "Penerapan Data Mining Untuk Menganalisis KeSatisfiedan Konsumen Menggunakan Metode Algoritma C4.5," J I M P - J. Inform. Merdeka Pasuruan, vol. 3, no. 3, pp. 34-38, 2018, doi: 
10.37438/jimp.v3i3.186.

[24] S. Santoso and R. Nurmalina, "Perencanaan dan Pengembangan Aplikasi Absensi Mahasiswa Menggunakan Smart Card Guna Pengembangan Kampus Cerdas (Studi Kasus Politeknik Negeri Tanah Laut),"J. Integr., vol. 9, no. 1, pp. 84-91, 2017.

[25] W. D. Septiani, P. Studi, and M. Informatika, "DAN NAIVE BAYES UNTUK PREDIKSI PENYAKIT HEPATITIS," vol. 13, no. 1, pp. 76-84, 2017. 